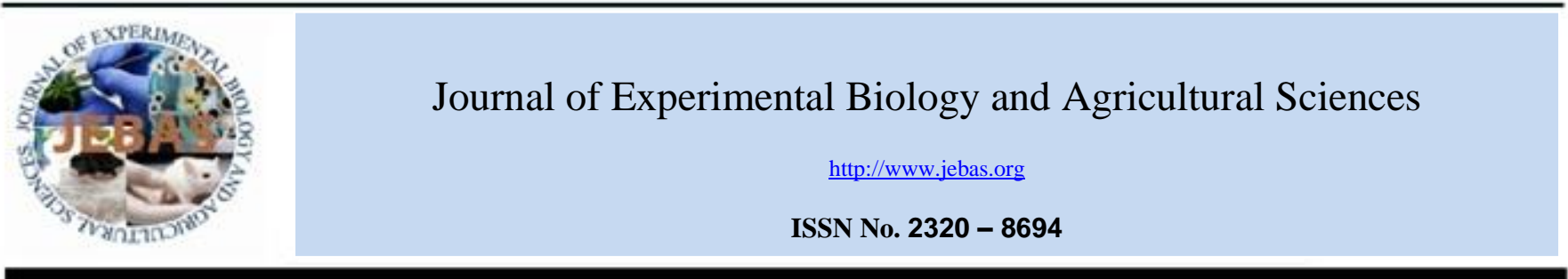

\title{
FUNCTIONAL AND MOLECULAR CHARACTERIZATION OF WHEAT RHIZOSPHERE BACTERIA AND THEIR ANTAGONISTIC ACTIVITY AGAINST WHEAT FOLIAR BLIGHT PATHOGENS
}

\author{
Vandana Jaggi $^{1 *}$, Samiksha Joshi ${ }^{1}$, Hemant Dasila $^{1}$, Navneet Pareek $^{2}$, Manvika Sahgal ${ }^{1 *}$ \\ ${ }^{1}$ Department of Microbiology, G.B. Pant University of Agriculture \& Technology, Pantnagar-263 145, Uttarakhand (India) \\ ${ }^{2}$ Department of Soil Sciences, G.B. Pant University of Agriculture \& Technology, Pantnagar-263 145, Uttarakhand (India)
}

Received - June 21, 2020; Revision - September 14, 2020; Accepted - October 13, 2020

Available Online - October 25, 2020

DOI: http://dx.doi.org/10.18006/2020.8(5).605.620

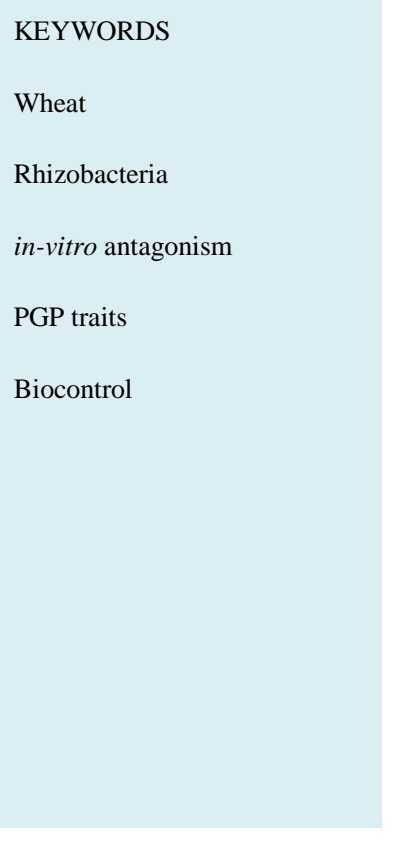

\begin{abstract}
The current study aimed to explore the wheat rhizospheric bacterial community for in vitro plant growthpromoting (PGP) traits and antagonistic activity against foliar blight disease of wheat caused by Alternaria triticina and Bipolaris sorokiniana. The soil samples from the wheat fields across four Indian states namely Uttarakhand (2 sites), Uttar Pradesh, Madhya Pradesh, and Maharashtra were analyzed for their physicochemical properties, enzymatic activities, and bacterial population density $\left(\mathrm{CFU} \mathrm{g}^{-1}\right)$. Amongst the tested soil samples, field soil from Uttar Pradesh has the highest bacterial population density $\left(2.5 \times 10^{7} \mathrm{CFU}\right.$ $\left.\mathrm{g}_{-}{ }^{1}\right)$ while the Uttarakhand (Almora) soil has the lowest (8.5x $10^{5} \mathrm{CFU} \mathrm{g-}{ }^{1}$ ). A total of 45 bacterial isolates recovered from all the sites were morphologically identified and screened for in-vitro solubilization of phosphate \& zinc, production of ammonia, siderophore, chitinase, protease, cellulase, amylase, lipase, and antagonistic activity. All isolates were found positive for one or more tested functional traits. Amongst 45 isolates, six showed $>50 \%$ inhibition of Alternaria triticina and Bipolaris sorokiniana mycelium, and three isolates P10, UP11 \& MH13 exhibited antagonistic activity against both the tested phytopathogens. Through 16S rDNA sequencing six putative biocontrol isolates, P10, UP11, MH13, MP17, MH12, and MP14 were identified as Bacillus methylotrophicus (MN099430.1), Bacillus subtilis (MN099431.1), Bacillus sp. (MN099432.1), Streptomyces sp. (MN099435.1), Lysinibacillus sp. (MN099433.1), and Staphylococcus epidermidis (MN099434.1). The selected wheat rhizobacteria exhibited PGP traits and biocontrol potential hence, may serve as putative biocontrol agents, for the management of foliar blight disease of wheat.
\end{abstract}

* Corresponding author

E-mail: vandanajaggi1234@gmail.com (Vandana Jaggi); sahgal.manvika@gmail.com (Manvika Sahgal)

Peer review under responsibility of Journal of Experimental Biology and Agricultural Sciences.

Production and Hosting by Horizon Publisher India [HPI] (http://www.horizonpublisherindia.in/).

All rights reserved.
All the articles published by Journal of Experimental Biology and Agricultural Sciences are licensed under a Creative Commons Attribution-NonCommercial 4.0 International License Based on a work at www.jebas.org.

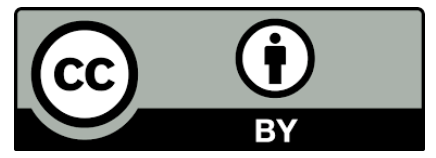




\section{Introduction}

Wheat (Triticum aestivum L.) is one of the principal crops for nearly 2.5 billion population world over with a total harvested area of 220 million hectares (Ramadas et al., 2019). In India, it is the second largest food crop after rice with 30 million hectares of cultivable area (Mahajan et al., 2017). To provide food security to the ever-increasing population, there is an imminent need to increase annual wheat production from the current 642 million tonnes to 840 million tonnes by the year 2050 (Sharma et al., 2015). The production of wheat is constrained by several biotic and abiotic stresses (Ali \& Baek, 2020). The warmer and humid regions of the world are mainly affected by fungal diseases. Among them, leaf blight caused by Alternaria triticina and spot blotch caused by Bipolaris sorokiniana (Sacc. in Sorok) are the two most devastating foliar blight diseases in warm and humid regions of India and other South Asian countries (Joshi \& Chand, 2002). In India, it is a major biotic constraint to wheat production in the Eastern Gangetic Plains encompassing the major wheat producing regions. Occasionally, in these regions, it occurs as a complex of leaf blight (Alternaria triticina) and spot blotch (Bipolaris sorokiniana) and is collectively referred to as foliar blight complex (Verma et al., 2020). Globally an estimated 25 million hectare of the wheat area is affected by the foliar blight of which, $40 \%$ area falls into the Indian subcontinent. The average annual crop losses are estimated to be 2-3 million tonnes (Gupta et al., 2018).

At present, the management of foliar blights is dependent on the seed treatment and foliar application of triazole group of fungicide such as tebuconazole, epoxiconazole, and propiconazole (Acharya et al., 2011). Despite the effectiveness of fungicides, these chemicals cause harmful effects, including disruption in soil microbiota, deteriorate soil quality, and environmental pollution (Li et al., 2015; Zhou et al., 2016). In this sense, biological control is a promising sustainable alternative that involves the use of plant beneficial microbes (Nafiu et al., 2016). The rhizosphere possesses a diverse group of plant beneficial microorganisms and also offers a quintessential habitat for the plant-microbe interactions. The complex plant-microbe interactions such as nutrients cycling, production of various plant growth promoting compounds, protection from phytopathogens by competing for the iron, production of antibiotics, lytic enzymes, detoxification and degradation of pathogen virulence factors improve the plant health and reduces the disease severity (Kaur et al., 2019; Kalam et al., 2020). Therefore, rhizobacteria with Plant growth promoting as well as antifungal enzyme production ability make them a suitable candidate for biocontrol agents. Many bacterial genera such as Paenibacillus, Pseudomonas, Burkholderia, Lysobacter, and Bacillus are considered as biocontrol agents since they produce a range of plant growth promoting compounds and antimicrobials
(Gouda et al., 2018; Villarreal-Delgado et al., 2018). Moreover, few studies have been reported the biological control of foliar blights under laboratory conditions. For instance, Bacillus sp. TSO2 (Villa-Rodriguez et al., 2019), and Chaetomium spp. (Yue et al., 2018) have been studied as potential bacterial antagonists against B. sorokiniana under In vitro conditions. Similarly, fluorescent pseudomonads and Bacillus spp. were found effective against A. triticina (Siddiqui, 2007). Besides this, till now no effective biocontrol agents have been commercialized against foliar blight pathogens. Hence, exploration of the diverse potential biocontrol strains that can sustain at different environmental conditions and soil type is a widely studied area of research for sustainable agriculture. Thus, the present study was aimed to explore the rhizospheric bacterial community for efficient bacterial antagonists against the foliar blight Pathogens/complex and to identify and characterize the putative bacterial antagonists through biochemical characteristics and 16S rDNA sequencing.

\section{Materials and methods}

\subsection{Collection of soil Samples}

The rhizospheric soil from wheat plants grown in farmer's fields were collected in November, 2018 from two sites at Uttarakhand i.e Almora $\left(29^{\circ} 35^{\prime} 39.08^{\prime \prime} \mathrm{N}\right.$ and $79^{\circ} 39^{\prime} 14.01^{\prime \prime}$ E, elevation 1,610 $\mathrm{m})$ and Pantnagar $\left(29^{\circ} 1^{\prime} 15.74^{\prime \prime} \mathrm{N}\right.$ and $79^{\circ} 29^{\prime} 23.06 " \mathrm{E}$, elevation $236.54 \mathrm{~m}$ ) and one site at Uttar Pradesh (27 54' 1.37" N and 78 $4^{\prime}$ 20.21" E, elevation $191 \mathrm{~m}$ ), Madhya Pradesh (24 $38^{\prime} 60.00^{\prime \prime} \mathrm{N}$ and $77^{\circ} 19^{\prime} 12.00^{\prime \prime}$ E, elevation $479 \mathrm{~m}$ ) and Maharashtra (19 59' $50.83^{\prime \prime} \mathrm{N}$ and $73^{\circ} 47^{\prime} 23.29^{\prime \prime}$ E, elevation $583 \mathrm{~m}$ ). The soil was collected from the rhizospheric zone at about $0-15 \mathrm{~cm}$ depth from ten randomly selected wheat plants. Subsequently, the soil from all plants was pooled to make a composite sample, put into sterile poly bags, and transferred to the laboratory in an icebox to isolate the bacteria.

\subsection{Estimation of soil physicochemical properties and enzyme activities}

The soil was dissolved in distilled water (DW) in the ratio, 1:5, and pH determined with century pH meter (model CP 931) (Miller \& Donochue 1990). Electrical conductivity (EC) of soil samples was assessed in $1: 25$ soil to water solution at $25^{\circ} \mathrm{C}$ with a digital microprocessor-based conductivity meter (Systronic Model 306). Organic carbon (OC) was determined by the Walkley-Black titration method (Walkley \& Black 1934) based on the oxidation of dichromate ion. Excess dichromate ion is back titrated with ferrous ion. Total $\mathrm{N}$ (TN) was estimated by the Kjeldahl digestion method (TKN). Available phosphorus (AP) content was measured colorimetrically after extraction with $0.5 \mathrm{~mol} \mathrm{l}^{-1} \mathrm{NaHCO}_{3}(\mathrm{pH} 8.5)$ for 30 minutes (Olsen et al., 1954). Available potassium (AK) content was determined by flame photometer after extraction with 
$1 \mathrm{~mol} \mathrm{NH}_{4} \mathrm{Ac}(\mathrm{pH}$ 7.0) for 30 minutes (Yuan, 1983). Minor trace elements like $\mathrm{Fe}, \mathrm{Zn}, \mathrm{Ca}, \mathrm{Mn}$, and $\mathrm{Mg}$ were measured by atomic absorption spectrometry (AAS) (Yao et al., 2003).

Also, the functional potential of the soil microbial communities inhabiting wheat rhizosphere was monitored through soil enzyme activities such as dehydrogenase (EC 1.1.1.) (DHA), fluorescein diacetate (FDA), acid phosphatase (EC 3.1.3.2) (ACP), alkaline phosphatase (EC 3.1.3.1) (ALP) and urease (EC 3.5.1.5) (URE). These enzymes activity was estimated through a spectrophotometer and compared with a standard curve. All assays were conducted in triplicates. DHA activity was assessed by Thalmann (1968). FDA activity was measured as described by Inbar et al. (1991). ACP and ALP activities were estimated by following the method of Tabatabai \& Bremner (1969). URE activity was assayed by following the method given by Kandeler \& Gerber (1988).

\subsection{Isolation of rhizobacteria}

Isolation of bacteria was carried through the conventional serial dilution method using Nutrient agar (NA) (composition $\mathrm{gl}^{-1}$ : Peptone $5 \mathrm{~g}$, beef extract $1 \mathrm{~g}$, yeast extract $2 \mathrm{~g}$, sodium chloride $5 \mathrm{~g}$, and agar 15g) (Majeed et al., 2015). Soil samples were serially diluted in normal saline and plated on NA. Plates were incubated at $30 \pm 2{ }^{\circ} \mathrm{C}$ for $12 \mathrm{~h}$. Bacterial colonies were counted and represented as colony forming unit $\left(\mathrm{CFU} \mathrm{\textrm {g } ^ { - 1 }}\right)$ per gram of soil. A total of forty five isolates with distinct colony morphology were purified by restreaking on NA plates.

\subsection{In vitro antagonism against $A$. triticina and $B$. sorokiniana}

A total of 45 rhizobacterial isolates were screened against two foliar blight pathogens through dual culture plate assay. Test fungal pathogens A. triticina (ITCC 1186) and B. sorokiniana (ITCC 4869) were collected from the Indian Type Culture Collection (ITCC), IARI, New Delhi, India. Fungal pathogens were cultured in potato dextrose agar (PDA) at $25 \pm 2^{\circ} \mathrm{C}$ for 5 7 days. A dual culture assay was performed against A. triticina and $B$. sorokiniana strain separately in half-strength NA-PDA medium. Agar plugs $(0.5 \mathrm{~cm}$ diameter) containing $A$. triticina and $B$. sorokiniana mycelia separately were placed at the center of halfstrength NA-PDA plates. Bacterial strains were streaked at equidistant points from the corners and incubated at $28^{\circ} \mathrm{C}$ for $5-7$ days. The experiment was conducted in triplicates. The antagonistic activity was estimated according to the formula given by Hazarika et al. (2019)

$\% \mathrm{MGI}=[(\mathrm{A} * \mathrm{~B}) / \mathrm{A}] \times 100$.

Where $\mathrm{A}$ is the fungal colony diameter on the control plate and $\mathrm{B}$ is the fungal colony diameter on the test plate.
2.5 Screening for multifarious plant growth promoting (PGP) attributes and antifungal enzymes

All isolates were screened for a wide array of PGP and antifungal traits. To check for ammonia production, actively growing bacterial isolates were inoculated in $10 \mathrm{ml}$ peptone water and incubated at $28 \pm 1^{\circ} \mathrm{C}$ at $120 \mathrm{rpm}$ for $72 \mathrm{~h}$ on a rotatory shaker. The Nessler's reagent $(1 \mathrm{ml})$ was added to the bacterial culture and observed for the production of ammonia. The colour change from yellow to brown indicates the production of ammonia (Cappuccino \& Sherman 1996). Phosphate solubilization was determined by spot inoculation of log-phase bacterial cultures on Pikovaskya's agar plates (composition: $\mathrm{gl}^{-1}$ Dextrose 10, Yeast extract 0.5, Calcium phosphate 5, Ammonium sulphate 0.5, Potassium chloride 0.2 , Magnesium sulphate 0.1 , ferrous sulphate 0.0001 , Manganese sulphate 0.0001, Agar 15). Thereafter, plates were incubated at $30^{\circ} \mathrm{C}$ for $48 \mathrm{~h}$ and observed for the clearance zone around bacterial spots, which indicated inorganic phosphate solubilization (Dutta \& Thakur 2017). Zinc solubilization ability was detected by spot inoculating log-phase bacterial cultures on minimal medium supplemented with zinc carbonate $(0.1 \%)$. The inoculated plates were incubated at $28 \pm 2^{\circ} \mathrm{C}$ for five days and were observed for the clearing zone around the colonies (Saravanan et al., 2004). Siderophore production was detected by spot inoculating log-phase bacterial cultures on chrome azurol S' (CAS) agar plates. Plates were incubated at $30^{\circ} \mathrm{C}$ for 5-6 days. The development of a yellow-orange halo zone around bacterial colonies against a dark blue background indicates siderophore production (Schwyn \& Neilands, 1987). To determine antifungal traits, firstly the chitinolytic activity of isolates was determined on a minimal agar medium containing (g/L) (NH4) ${ }_{2} \mathrm{SO}_{4} 1 \mathrm{~g}, \mathrm{~K}_{2} \mathrm{HPO}_{4} 1 \mathrm{~g}, \mathrm{NaCl} 0.1 \mathrm{~g}$, $\mathrm{MgSO}_{4} .7 \mathrm{H}_{2} \mathrm{O} 0.5 \mathrm{~g}$, yeast extract $0.5 \mathrm{~g}$, agar and $15 \mathrm{~g}$ supplemented with $0.5 \%$ colloidal chitin. The minimal agar plates, spot inoculated with log-phase bacterial culture were incubated at $30^{\circ} \mathrm{C}$ for 5-6 days and observed for the halo zone around colonies (Sadfi et al., 2001). Amylase production by bacterial isolates was tested by growing them on glucose yeast extract peptone agar (GYP) $\mathrm{pH}$ 6.0 supplemented with $0.2 \%$ soluble starch (Kasana et al., 2008). The inoculated plates were incubated at $30^{\circ} \mathrm{C}$ for two days. Thereafter, plates were flooded with $1 \%$ iodine in $2 \%$ potassium iodide to visualize the zone of clearance. Protease production was determined by spotting active bacterial cultures on skim milk agar plates (Skim milk powder 28.0, Tryptone 5.0, Yeast extract 2.5, Dextrose 1.0, Agar $15.0 \mathrm{gl}^{-1}, \mathrm{pH} 7.0 \pm 0.2$ ) and incubated at $28-30^{\circ} \mathrm{C}$ for 2 days. The clear halo zone around bacterial growth indicated the protease production (Shaheen et al., 2008). To detect lipase production, log-phase bacterial cultures were inoculated on nutrient agar plates containing $1 \%(\mathrm{w} / \mathrm{v})$ tween 80 . The deposition of precipitate around the colony or halos indicated the positive test. The pectinolytic activity was assessed by spot inoculating the bacterial cultures on agar plates containing $1 \%$ pectin. The plates 
were incubated at $28^{\circ} \mathrm{C}$ for $48 \mathrm{~h}$. Thereafter, plates were flooded with iodine solution ( $1 \%$ iodine in $2 \%$ potassium iodide). A clear halo zone around the bacterial colony indicated pectinolytic activity (Joshi et al., 2019).

\subsection{Ranking of bacterial isolates}

All 45 rhizobacterial isolates were ranked based on the bonitur scale (Krechel et al., 2002). Bonitur score included the points ( $\Sigma$ =29) for all functional attributes i.e. PGP, antifungal traits, and antagonistic activity. Each property is assigned 1 to 3 points. The distributions of the points are as follows: three points each for $\mathrm{P}$ solubilization, $\mathrm{Zn}$ solubilization, Siderophore production, protease, pectinase, chitinase, and amylase activities $(\Sigma=21)$. Whereas, one point each for ammonia production and lipase activity $(\Sigma=2)$ and 3 points each to in-vitro antagonism against $A$. triticina and $B$. sorokiniana $(\Sigma=6)$.

\subsection{Morphological and biochemical characterization of poten bacterial antagonists}

For the primary identification and characterization, morphological and biochemical tests are still one of the key criterions utilized (Rai et al., 2014). Morphological characterization was done to determine the colony characteristics of the bacterial isolates on NA plates and through Gram's reaction. The biochemical tests viz., catalase, urease, voges-proskauer, and methyl red were performed as per the standard procedures (Jain et al., 2020).

Also, carbon source utilization patterns of efficient bacterial antagonists were analyzed using TM HiCarbo Kit (HiMedia Laboratories) containing 35 carbon sources (Table 6). This is a standardized colorimetric identification system based on the principle of $\mathrm{pH}$ change and substrate utilization. To test carbohydrate utilization, the test strips were pre-inoculated with $100 \mu \mathrm{l}$ of bacterial culture and incubated at $30^{\circ} \mathrm{C}$ for $12-48 \mathrm{~h}$. On incubation, organisms undergo metabolic changes which are indicated by a spontaneous colour change (red to yellow) in the medium. The test provides a "metabolic fingerprint" of the microorganism that can be used to identify the metabolic diversity among the microorganism.

\subsection{DNA isolation and molecular identification of potent bacterial antagonists}

The total genomic DNA isolation of bacterial isolates was carried out following the method outlined by Joshi et al. (2019). Thereafter, the 16S rDNA gene was amplified using the forward GM3f (5'TACCTTGTTGTTACGACTT3') and reverse GM4r (5'TACCTTGTTACGACTT3') universal primers set (Rajwar \& Sahgal, 2016). The PCR reaction was carried out in $50 \mu 1$ reaction mixture containing the following components: $1 \times \mathrm{PCR}$ buffer,
50 ng DNA template, $0.5 \mathrm{mM} \mathrm{MgCl}_{2}, 400 \mu \mathrm{M}$ dNTP mixture and $0.25 \mu \mathrm{M}$ each of primer, and one unit of Taq Polymerase (Bangalore Genie, India) in a thermal cycler (Applied Biosystems GeneAmp PCR 9700) under the following cycling conditions (initial denaturation $5 \mathrm{~min}$ at $95^{\circ} \mathrm{C}$, followed by 35 cycles of $1 \mathrm{~min}$ at $94^{\circ} \mathrm{C}, 1 \mathrm{~min}$ at $52^{\circ} \mathrm{C}$ and $1 \mathrm{~min}$ at $72^{\circ} \mathrm{C}$ with the final extension of $5 \mathrm{~min}$ at $72^{\circ} \mathrm{C}$ ). Amplified products were resolved in $1.0 \%$ agarose gel using $1 \times$ TAE buffer till the bands resolved. The gel was visualized under the UV documentation imaging system GelDocMega (Biosystematica).

The PCR product was purified using a GeneiPure gel extraction kit (Banglore Genei, India) following the manufacturer's instruction. Subsequently, it was sequenced directly on 3730 DNA sequencer using ABI big dye terminator technology at Central Instrumental Facility, Biotech Centre, UDSC, New Delhi. The obtained DNA sequences were edited using the software, Genomics Workbench 20.0. Similarity search for the sequences was carried out and compared with the $16 \mathrm{~S}$ rDNA sequences of related species available in GenBank databases using the BLAST search program of the National Center for Biotechnology Information (NCBI) at http://www.ncbi.n1m.nih.gov/blast/Blast.cgi (Shrestha et al., 2016). The BLAST results revealed the identity of the query sequences based on their percentage query coverage and sequence similarity. Thereafter, sequences were submitted to the NCBI GenBank database and accession numbers were obtained. A phylogenetic tree was constructed by the neighbor-joining method using MEGA 7.0 (Tamura et al., 2013). Bootstrap replication (1000 replications) was used as statistical support for the nodes in the phylogenetic tree.

\subsection{Statistical analysis}

All the experiments were conducted in triplicates. The data of soil physicochemical properties, enzyme activities, and antagonistic assay were statistically analyzed through one-way analysis of variance (ANOVA) via Duncan's multiple range tests at the $P \leq$ 0.05 significance level using SPSS (IBM SPSS Statistics version 16) software package and presented as means \pm standard error (SE). Pearson's correlation analysis and graphing were performed using R 3.4.2 software.

\section{Results and Discussion}

\subsection{Soil physicochemical properties and enzyme activities}

The soil physicochemical characteristics revealed soil nutrient status and health. The soil texture of Almora and Pantnagar was silty clay loam, Uttar Pradesh was clay loam and that of Madhya Pradesh and Maharashtra was sandy clay loam (Table 1). The soil $\mathrm{pH}$ of Almora was lowest i.e. 6.2, this was followed by Pantnagar (7.1), Uttar Pradesh (7.8), Madhya Pradesh (8.0), and Maharashtra 
Table 1 Geographical locations of sampling sites, soil type and bacterial density (Cfu g $\left.{ }^{-1}\right)$

\begin{tabular}{|c|c|c|c|c|c|}
\hline \multicolumn{2}{|c|}{ Sampling sites } & Location & Soil type (USDA) & No of isolates & $\mathrm{Cfu} \mathrm{g}^{-1}$ soil \\
\hline \multirow{2}{*}{ Uttarakhand } & Almora & $\begin{array}{l}29^{\circ} 35^{\prime} 39.08^{\prime \prime} \mathrm{N} \\
79^{\circ} 39^{\prime} 14.01^{\prime \prime} \mathrm{E}\end{array}$ & Silty clay loam & 9 & $8.5 \times 10^{5}$ \\
\hline & Pantnagar & $\begin{array}{c}29^{\circ} 1 ' 15.74 " \mathrm{~N} \\
79^{\circ} 29^{\prime} 23.06^{\prime \prime} \mathrm{E}\end{array}$ & Silty clay loam & 9 & $1.3 \times 10^{7}$ \\
\hline Uttar Pradesh & & $\begin{array}{l}27^{\circ} 54^{\prime} 1.37^{\prime \prime} \mathrm{N} \\
78^{\circ} 4^{\prime} 20.21^{\prime \prime} \mathrm{E}\end{array}$ & Clay loam & 10 & $2.5 \times 10^{7}$ \\
\hline Madhya Pradesh & & $\begin{array}{l}24^{\circ} 38^{\prime} 60.00^{\prime \prime} \mathrm{N} \\
77^{\circ} 19^{\prime} 12.00^{\prime \prime} \mathrm{E}\end{array}$ & Sandy clay loam & 8 & $1.26 \times 10^{7}$ \\
\hline Maharashtra & & $\begin{array}{l}19^{\circ} 59^{\prime} 50.83^{\prime \prime} \mathrm{N} \\
73^{\circ} 47^{\prime} 23.29^{\prime \prime} \mathrm{E}\end{array}$ & Sandy clay loam & 9 & $1.38 \times 10^{7}$ \\
\hline
\end{tabular}

Table 2 Soil Physicochemical properties and enzyme activities of rhizospheric soil samples collected from wheat growing regions of India

\begin{tabular}{|c|c|c|c|c|c|}
\hline \multirow{3}{*}{ Parameters } & \multicolumn{5}{|c|}{ Sampling sites } \\
\hline & \multicolumn{2}{|c|}{ Uttarakhand } & \multirow{2}{*}{ Uttar Pradesh } & \multirow{2}{*}{ Madhya Pradesh } & \multirow{2}{*}{ Maharashtra } \\
\hline & Almora & Pantnagar & & & \\
\hline OC $\%$ & $0.45 \pm 0.011^{\mathrm{a}}$ & $0.84 \pm 0.013^{\mathrm{a}}$ & $1.4 \pm 0.011^{\mathrm{a}}$ & $0.97 \pm 0.012^{\mathrm{a}}$ & $0.98 \pm 0.006^{\mathrm{a}}$ \\
\hline OM\% & $0.7 \pm 0.02^{\mathrm{a}}$ & $1.43 \pm 0.03^{\mathrm{a}}$ & $2.4 \pm 0.02^{\mathrm{a}}$ & $1.56 \pm 0.18^{\mathrm{b}}$ & $1.69 \pm 0.02^{\mathrm{a}}$ \\
\hline soil $\mathrm{pH}$ & $6 \pm 0.11^{\mathrm{a}}$ & $7.23 \pm 0.08^{\mathrm{b}}$ & $7.53 \pm 0.14^{\mathrm{b}}$ & $7.96 \pm 0.14^{\mathrm{b}}$ & $8.26 \pm 0.14^{\mathrm{b}}$ \\
\hline $\mathrm{EC}(\mu \mathrm{s} / \mathrm{cm})$ & $33.91 \pm 0.02^{\mathrm{c}}$ & $27.28 \pm 0.01^{\mathrm{c}}$ & $31.27 \pm 0.02^{\mathrm{e}}$ & $43.6 \pm 0.01^{\mathrm{c}}$ & $151.6 \pm 0.80^{\mathrm{h}}$ \\
\hline AV P (kg/hectare) & $41 \pm 6.83^{\mathrm{d}}$ & $55.66 \pm 0.66^{g}$ & $68 \pm 2.88^{f}$ & $62.66 \pm 0.88^{\mathrm{e}}$ & $50.66 \pm 2.08^{\mathrm{e}}$ \\
\hline AV K (kg/hectare) & $264.66 \pm 2.72^{f}$ & $293.66 \pm 1.45^{\mathrm{h}}$ & $389.33 \pm 1.76^{\mathrm{g}}$ & $315.66 \pm 2.33^{g}$ & $364 \pm 3.05^{\mathrm{i}}$ \\
\hline $\mathrm{NH}_{4}-\mathrm{N}(\mathrm{kg} /$ hectare $)$ & $34.66 \pm 2.72^{\mathrm{c}}$ & $50.33 \pm 1.76^{\mathrm{gf}}$ & $22 \pm 1.73^{\mathrm{h}}$ & $40.33 \pm 1.76^{\mathrm{c}}$ & $32.66 \pm 2.90^{\mathrm{d}}$ \\
\hline $\mathrm{NO}_{3}-\mathrm{N}(\mathrm{kg} /$ hectare $)$ & $21.33 \pm 2.33^{\mathrm{a}}$ & $47.66 \pm 1.20^{\mathrm{f}}$ & $12 \pm 1.73^{\mathrm{d}}$ & $41.66 \pm 2.02^{\mathrm{c}}$ & $16.33 \pm 2.02^{\mathrm{c}}$ \\
\hline $\mathrm{Zn}\left(\mu \mathrm{g} \mathrm{ml}^{-1}\right)$ & $0.84 \pm 0.02^{\mathrm{a}}$ & $0.74 \pm 0.02^{\mathrm{a}}$ & $1.74 \pm 0.02^{\mathrm{bc}}$ & $0.95 \pm 0.02^{\mathrm{a}}$ & $1.23 \pm 0.02^{\mathrm{a}}$ \\
\hline $\mathrm{Fe}\left(\mu \mathrm{g} \mathrm{ml}^{-1}\right)$ & $0.23 \pm 0.01^{\mathrm{a}}$ & $4.44 \pm 0.03^{\mathrm{b}}$ & $14.21 \pm 0.02^{\mathrm{a}}$ & $0.233 \pm 0.02^{\mathrm{a}}$ & $1.16 \pm 0.01^{\mathrm{a}}$ \\
\hline
\end{tabular}

(8.5). Electrical conductivity for Almora, Pantnagar, Uttar Pradesh, Madhya Pradesh, and Maharashtra was 33.96, 27.29, 31.31, 43.63, $152.4 \mu \mathrm{s} \mathrm{cm}^{-1}$ respectively. Uttar Pradesh soil had the highest percentage of organic carbon (\%OC) $(1.4 \%)$ while the lowest was reported for Almora soil $(0.43 \%)$. The macro and micronutrients (available phosphorous, Potassium, iron, and zinc) were highest in Uttar Pradesh and lowest in Almora (Table 2). The study is supported by several reports, for instance, Maurya et al., 2011 stated that the soil of Almora is acidic and deficit in available phosphorous content. Baqir et al., 2018 reported that the $\mathrm{pH}$ of soil from Uttar Pradesh was slightly alkaline (6.78 to 8.21) with higher organic matter, nitrogen, phosphorus, and potassium content.

Soil nutrient status and soil enzyme activities are correlated. Moreover, soil enzymes are well known to play a significant role in soil health and their environment. DHA, FDA, and ALP enzyme activities were significantly $(p<0.05)$ higher in soil samples of Uttar Pradesh as compared to samples from other regions whereas, ACP and URE activities were higher in soil samples from Almora and Pantnagar respectively. These findings indicated a vast difference in soil enzyme activities concerning the sampling site. The difference may be due to the agro-ecological variations between the sampling regions. Also, the soil enzyme activities vary with soil type in quantity and level of activity (Veeraragavan et al., 2018). Moreover, the soil enzyme activities have broad-scale spatial variability at any location and are expected to vary to an extent according to the direction and spacing of sampling points (Tan et al., 2014).

Soil enzymes produced by microorganisms play a substantial role in nutrient cycling. The results from this and numerous other studies have indicated that the level of macro and micronutrient status in soil affects enzyme activities (Jian et al., 2016; Wang et al., 2018; Ullah et al., 2019). Pearson's correlation matrix among soil physicochemical properties and enzyme activities revealed a positive as well as a negative correlation between soil properties (Figure 1). For example, soil organic matter (OM) content was significantly correlated with DHA, FDA, and URE activities. However, there was a negative correlation between available phosphorous (AVP) and nitrogen content $\left(\mathrm{NH}_{4}-\mathrm{N}\right.$ and $\left.\mathrm{NO}_{3}-\mathrm{N}\right)$ to the acid and alkaline phosphatase and urease activity respectively. These results are supported by findings of several earlier studies that showed the positive correlation among enzyme activities and soil organic matter, the major energy source for microorganisms (Liu et al., 2020). Earlier Tan et al. (2014) reported that soil organic matter influences soil properties and nutrient cycling. In contrast Nannipieri et al., 2017 observed a negative correlation 


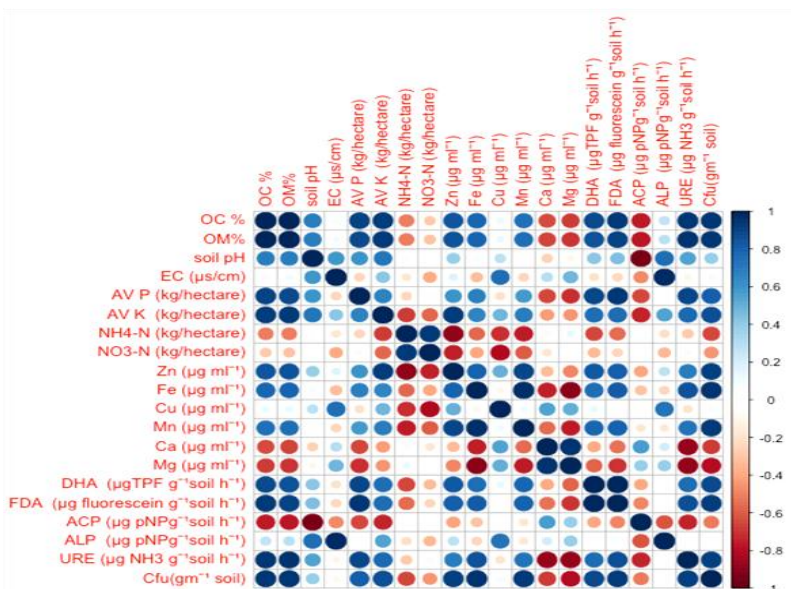

Figure1. Correlation coefficient matrix of Pearson's correlation analysis of soil physicochemical properties and enzyme activities. The circle size and color scale and both represent the correlation coefficient. It ranged from -1 (red color) negative correlation to +1 (blue color) strong positive correlation.

between $\mathrm{P}$ availability and phosphatase activity. In P-deficient soils, phosphatase secretion from plant roots increases to enhance phosphate availability to plants (Bueis et al., 2018). Similarly, Urease activity was also negatively correlated with $\mathrm{NH}_{4}-\mathrm{N}$ and $\mathrm{NO}_{3}-\mathrm{N}$ content of soil (Wang et al., 2014; Xu et al., 2015). The findings of this study proved that biological (microbial and biochemical) activity in soil plays a key role in nutrient cycling and is responsible for the wide ecological functions of soil.

\subsection{Isolation of bacteria from rhizospheric soil}

The bacterial population in wheat rhizospheric soil at five sites Almora, Pantnagar, Uttar Pradesh, Madhya Pradesh, and Maharashtra, India varied from $8 \times 10^{5}$ to $2.5 \times 10^{7} \mathrm{cfu}^{-1}$. The population was highest at Uttar Pradesh $\left(2.5 \times 10^{7} \mathrm{cfug}^{-1}\right)$ and lowest at Almora $\left(8.5 \times 10^{5} \mathrm{cfug}^{-1}\right)$. A total of 45 bacterial isolates, 18 from Uttarakhand ( 2 sites, 9 from each site), 10 from Uttar Pradesh, 9 from Madhya Pradesh, and 8 from Maharashtra were recovered and identified based on distinct morphological characteristics (Table 1). Further, they were screened for in-vitro antagonistic and plant growth-promoting activity. The rhizosphere is considered a hot spot of bacterial diversity due to the rhizodeposition. Rhizobacteria associated with cereals especially wheat under different ecological conditions have been isolated and studied for PGP and antifungal traits in several studies (Zhang et al., 2012; Majeed et al., 2015). Verma et al. (2016) found that average bacteria populations in soil collected from wheat fields in Uttar Pradesh ranged from $6 \times 10^{6}$ to $1 \times 10^{8} \mathrm{cfug}^{-1}$.

\subsection{In- vitro antagonism against $A$. triticina and $B$. sorokiniana}

All forty-five rhizobacterial isolates showed varying degrees of antagonism against both the pathogens. The degree of antagonism ranged from 12.22 to $65 \%$ against A. triticina whereas 12.59 to $69.14 \%$ against $B$. sorokiniana (Table 3). Out of the forty-five isolates,
Table 3 In vitro antagonistic activity of selected bacterial isolates against $B$. sorokiniana and A.triticina

\begin{tabular}{|c|c|c|}
\hline Bacterial Isolates & $\begin{array}{c}\% \text { MGI } \\
\text { (B.sorokiniana) }\end{array}$ & $\% \mathrm{MGI}$ (A. triticina) \\
\hline A1 & $32.96 \pm 0.97^{\mathrm{a}}$ & $20.37 \pm 0.97^{\mathrm{ab}}$ \\
\hline $\mathrm{A} 2$ & $21.11 \pm 1.28^{\mathrm{c}}$ & $29.62 \pm 0.97^{\mathrm{ab}}$ \\
\hline $\mathrm{A} 3$ & $20 \pm 1.69^{\mathrm{bc}}$ & $26.29 \pm 0.74^{\mathrm{ab}}$ \\
\hline A4 & $28.88 \pm 1.11^{\mathrm{c}}$ & $30.74 \pm 1.61^{\text {ef }}$ \\
\hline A6 & $32.222 \pm 1.11^{\mathrm{a}}$ & $20.37 \pm 1.33^{\text {ef }}$ \\
\hline A12 & $27.03 \pm 0.74^{\mathrm{c}}$ & $31.11 \pm 1.11^{\text {cde }}$ \\
\hline A15 & $18.14 \pm 1.48^{\mathrm{a}}$ & $17.03 \pm 1.33^{\mathrm{a}}$ \\
\hline A19 & $23.33 \pm 0.64^{\mathrm{a}}$ & $19.25 \pm 1.33^{\mathrm{abc}}$ \\
\hline $\mathrm{A} 21$ & $24.81 \pm 0.37^{\mathrm{ab}}$ & $22.22 \pm 1.11^{\text {bcd }}$ \\
\hline P1 & $33.33 \pm 1.11^{\mathrm{b}}$ & $40 \pm 2.31^{\mathrm{b}}$ \\
\hline $\mathrm{P} 2$ & $37.4 \pm 1.33^{\mathrm{bc}}$ & $32.22 \pm 2.93^{\mathrm{bc}}$ \\
\hline P3 & $38.14 \pm 1.33^{\mathrm{bc}}$ & $28.51 \pm 1.48^{\mathrm{b}}$ \\
\hline $\mathrm{P} 4$ & $18.51 \pm 0.97^{\mathrm{bc}}$ & $38.88 \pm 1.69^{\mathrm{ab}}$ \\
\hline P5 & $12.59 \pm 0.97^{\mathrm{c}}$ & $32.96 \pm 1.61^{\mathrm{ab}}$ \\
\hline P6 & $18.51 \pm 2.67^{\mathrm{a}}$ & $40 \pm 1.69^{\mathrm{bc}}$ \\
\hline P7 & $39.62 \pm 2.59^{\mathrm{a}}$ & $22.22 \pm 1.69^{\mathrm{b}}$ \\
\hline P9 & $27.4 \pm 1.48^{\mathrm{bcd}}$ & $15.55 \pm 1.11^{\mathrm{a}}$ \\
\hline P10 & $69.14 \pm 2.02^{\mathrm{c}}$ & $65 \pm 1.60^{\mathrm{bcd}}$ \\
\hline UP1 & $18.88 \pm 1.28^{\mathrm{d}}$ & $18.14 \pm 1.85^{\mathrm{c}}$ \\
\hline UP2 & $26.66 \pm 1.11^{\mathrm{c}}$ & $12.59 \pm 2.06^{\mathrm{a}}$ \\
\hline UP3 & $37.77 \pm 1.11^{\mathrm{b}}$ & $41.11 \pm 1.92^{\mathrm{bc}}$ \\
\hline UP4 & $42.59 \pm 0.74^{\mathrm{a}}$ & $28.88 \pm 1.92^{\mathrm{ab}}$ \\
\hline UP5 & $37.03 \pm 0.97^{\mathrm{e}}$ & $37.77 \pm 1.11^{\mathrm{ab}}$ \\
\hline UP6 & $25.92 \pm 0.97^{b}$ & $23.33 \pm 1.69^{\mathrm{e}}$ \\
\hline UP7 & $16.66 \pm 0.64^{\mathrm{a}}$ & $23.33 \pm 2.22^{\mathrm{b}}$ \\
\hline UP9 & $31.85 \pm 0.97^{\mathrm{a}}$ & $27.4 \pm 1.61^{\mathrm{a}}$ \\
\hline UP10 & $14.81 \pm 0.97^{\mathrm{e}}$ & $31.48 \pm 1.85^{\mathrm{a}}$ \\
\hline UP11 & $66.92 \pm 0.87^{\mathrm{c}}$ & $62.37 \pm 1.93^{\mathrm{ef}}$ \\
\hline MP4 & $17.4 \pm 0.74^{\mathrm{b}}$ & $29.62 \pm 2.06^{\mathrm{e}}$ \\
\hline MP5 & $32.59 \pm 0.74^{\mathrm{b}}$ & $34.81 \pm 1.33^{\mathrm{a}}$ \\
\hline MP12 & $27.03 \pm 1.48^{\text {cd }}$ & $12.22 \pm 1.69^{\mathrm{a}}$ \\
\hline MP14 & $51.88 \pm 0.33^{\mathrm{de}}$ & $21.48 \pm 1.95^{\mathrm{a}}$ \\
\hline MP16 & $46.29 \pm 0.37^{\mathrm{de}}$ & $24.44 \pm 2.31^{\mathrm{a}}$ \\
\hline MP17 & $56.33 \pm 0.83^{\mathrm{e}}$ & $24.07 \pm 0.74^{\mathrm{d}}$ \\
\hline MP20 & $37.77 \pm 1.11^{\mathrm{a}}$ & $27.77 \pm 1.69^{\mathrm{a}}$ \\
\hline MP22 & $31.11 \pm 1.69^{\mathrm{ab}}$ & $21.48 \pm 1.33^{\mathrm{a}}$ \\
\hline MH6 & $39.25 \pm 2.25^{\mathrm{ab}}$ & $26.66 \pm 2.22^{\mathrm{b}}$ \\
\hline MH10 & $29.62 \pm 2.25^{\mathrm{ab}}$ & $25.55 \pm 1.28^{\mathrm{a}}$ \\
\hline MH11 & $34.44 \pm 1.11^{\mathrm{ab}}$ & $29.25 \pm 1.33^{\mathrm{b}}$ \\
\hline MH12 & $43.7 \pm 0.74^{b}$ & $55.25 \pm 1.40^{\mathrm{def}}$ \\
\hline MH13 & $63.40 \pm 2.95^{\mathrm{d}}$ & $58.37 \pm 1.73^{\text {def }}$ \\
\hline MH14 & $38.88 \pm 1.69^{\mathrm{d}}$ & $19.62 \pm 1.61^{\mathrm{a}}$ \\
\hline MH16 & $27.77 \pm 1.69^{\mathrm{a}}$ & $41.11 \pm 1.69^{\mathrm{bc}}$ \\
\hline MH17 & $31.11 \pm 1.69^{\mathrm{e}}$ & $26.29 \pm 1.33^{\mathrm{ab}}$ \\
\hline MH20 & $28.14 \pm 0.74^{\mathrm{bc}}$ & $24.81 \pm 1.95^{\mathrm{c}}$ \\
\hline
\end{tabular}


four showed $>50 \%$ antagonism against $A$. triticina and five against $B$. sorokiniana (Figure 2). The three isolates P10, UP11, and MH13 showed more than 50\% antagonism against both the test pathogens. Several earlier studies have reported the in vitro inhibition of $A$. triticina and $B$. sorokiniana through diverse microbial antagonists. For instance, Actinomyces sp. (Monterio et al., 2017), Trichoderma spp. (Dal Bello et al., 2008) and Pseudomonas fluorescens UBSPF-10 (Singh et al., 2019a) suppressed the mycelia growth of B. sorokiniana by $44 \%, 51 \%$, and $67.96 \%$ respectively. Similarly, Bacillus subtilis TE3, able to inhibit the mycelial growth of B. sorokiniana by $55 \%$ in-vitro (Villa-Rodriguez et al., 2019). Sood et al. (2020), reported that rhizobacterial isolate Serratia marcescens B2 effective in vitro inhibition of $B$. sorokiniana mycelia. A year the later same group of workers found that ten tested Bacillus sp. showed broad-spectrum antagonistic activity against Alternaria triticina and Fusarium graminearum in-vitro. The bacterial production of antifungal traits is reported as reason of antagonism (Tsegaye et al., 2019).

\subsection{Multifarious Plant growth promoting (PGP) attributes and antifungal enzymes}

All 45 rhizobacteria exhibited PGP traits like the production of ammonia and siderophore, phosphate and $\mathrm{Zn}$-solubilization (Figure 3A). Out of 45 isolates, $51.11 \%$ were positive for ammonia, and $62.22 \%$ for siderophore production. Likewise, $26.66 \%$ were positive for P-solubilization and $60 \%$ for $\mathrm{Zn}$-solubilization. Besides, these isolates also exhibited the production of chitinase, amylase, protease, lipase, and pectinase enzymes. Out of these, $64.44 \%$ were considered to be positive for amylase, $57.77 \%$ for pectinase, $35.55 \%$ for protease, $26.66 \%$ for chitinase, and $17.77 \%$ for lipase activity (Figure 3B). Many microorganisms capable of solubilizing insoluble phosphate and zinc have been isolated from the rhizosphere of cereal crops (Rana et al., 2011). Sood et al. (2019) recovered three bacterial isolates (B2, SIR1, and BIS2) positive for phosphate solubilization, siderophore production, and ammonia production for wheat rhizosphere. Application of rhizobacteria with PGP traits and hydrolytic enzyme production enhance the plant growth and reduce the growth of phytopathogenic fungi in the plant rhizosphere. For example, wheat rhizospheric bacteria PRP-6 can produce ammonia, solubilize phosphate, and excrete lytic enzyme. The use of these bacteria as biofertilizers reduced the growth of the fungal pathogen, Fusarium oxysporum resulting in increased plant growth (Jadoon et al., 2019). Similarly, rhizobacterial isolate Pseudomonas sp M2 that can produce siderophore and hydrolytic enzymes (protease, cellulase, and chitinase) is a putative biofertilizer (Joshi \& Dhingani, 2020). These examples support the hypothesis that bacteria producing hydrolytic enzymes act as agents for the prevention of plant diseases by causing lysis of pathogenic microbes found in the close vicinity of the plants (Tsegaye et al., 2019).

The bacterial isolates were ranked based on points they scored through the bonitur scale ( $\Sigma=29$ points) (Table 4$)$. The isolates scoring more than 12 points on the bonitur scale $(\Sigma=>12)$ were selected as potential bacterial isolates and further processed for characterization. In this study, six bacterial isolates scored $>12$ points. Among them, P10
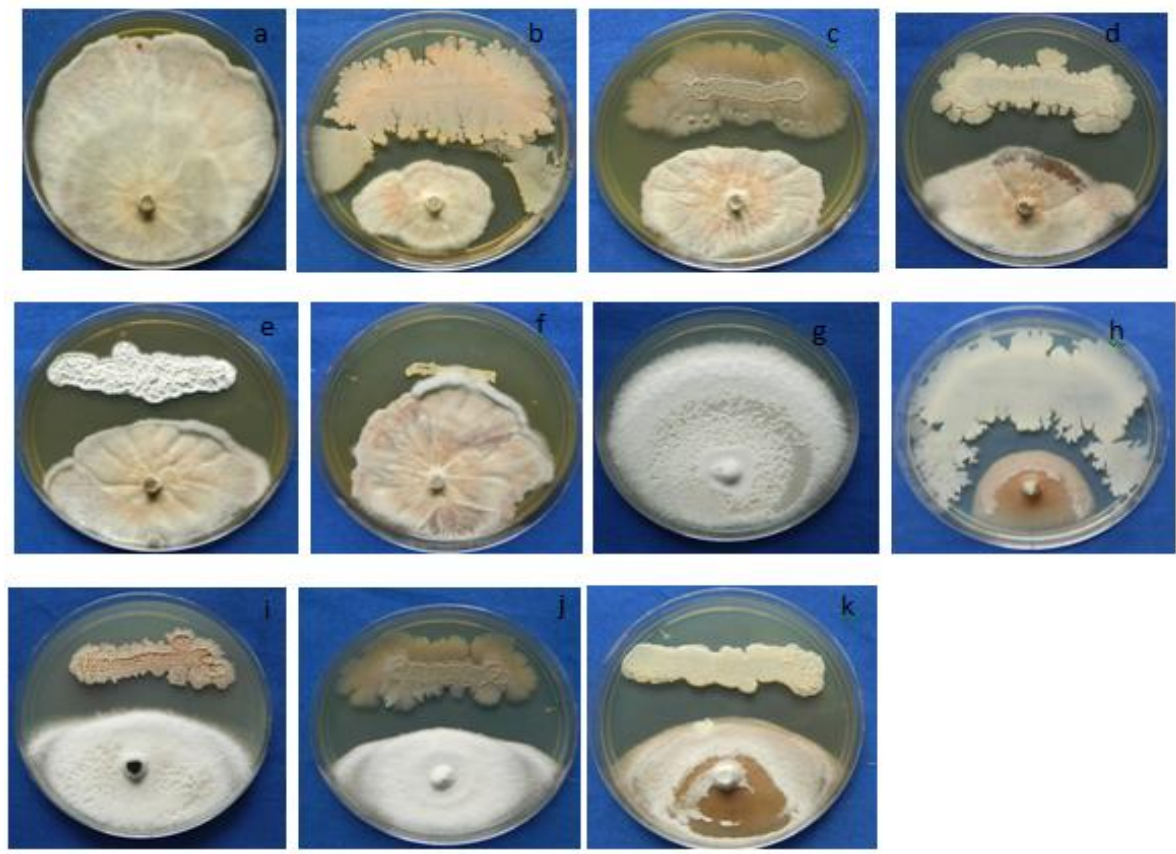

Figure 2 Antagonistic activity against test fungus in a dual plat assay; fig (a-f) showing the results of in-vitro antagonism against $B$. sorokiniana, Control, P10, UP11, MH13, MP17 and MP14 isolates and fig (g-k) against A. triticina, control, P10, UP11, MH13 and MH12 respectively.

Journal of Experimental Biology and Agricultural Sciences http://www.jebas.org 

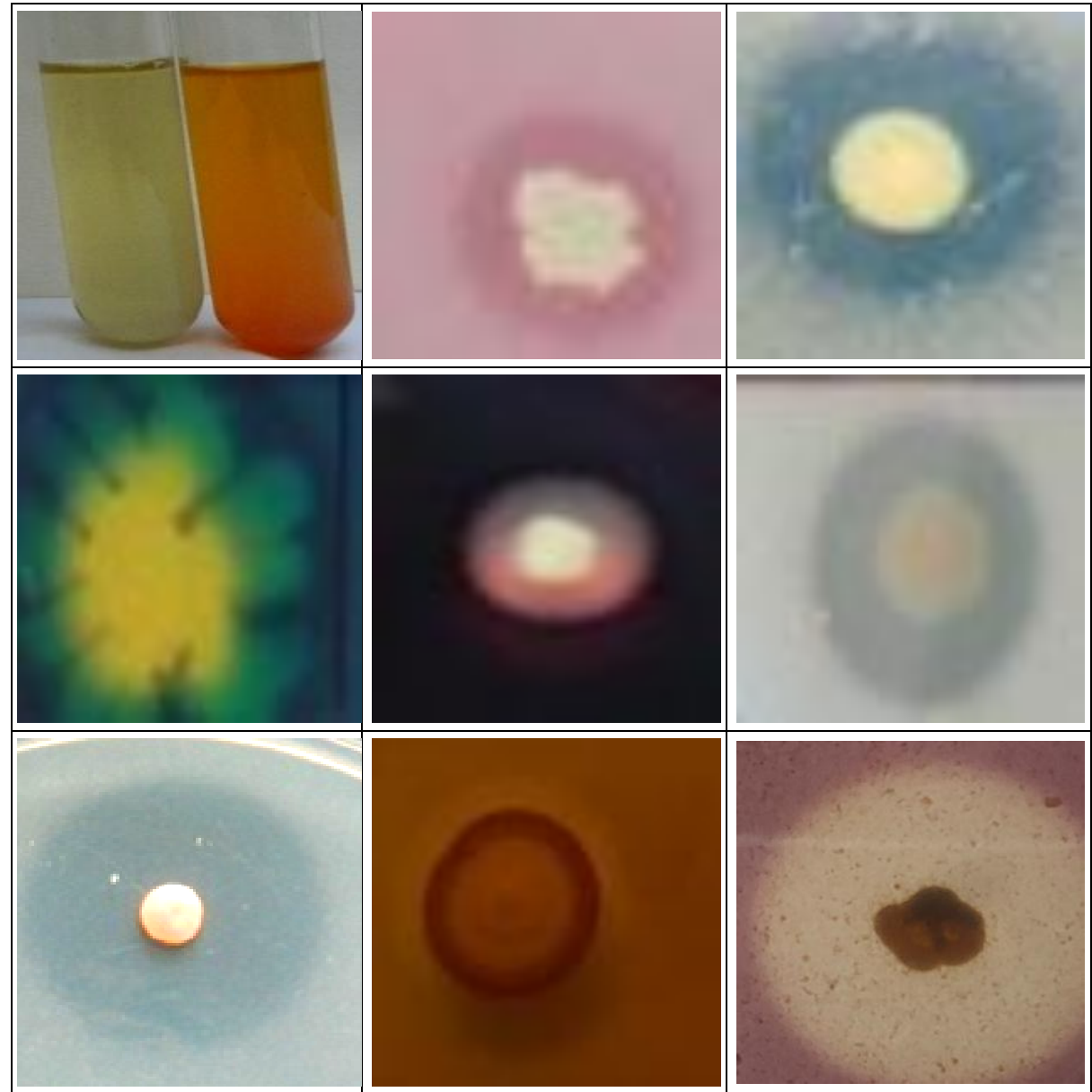

(A)
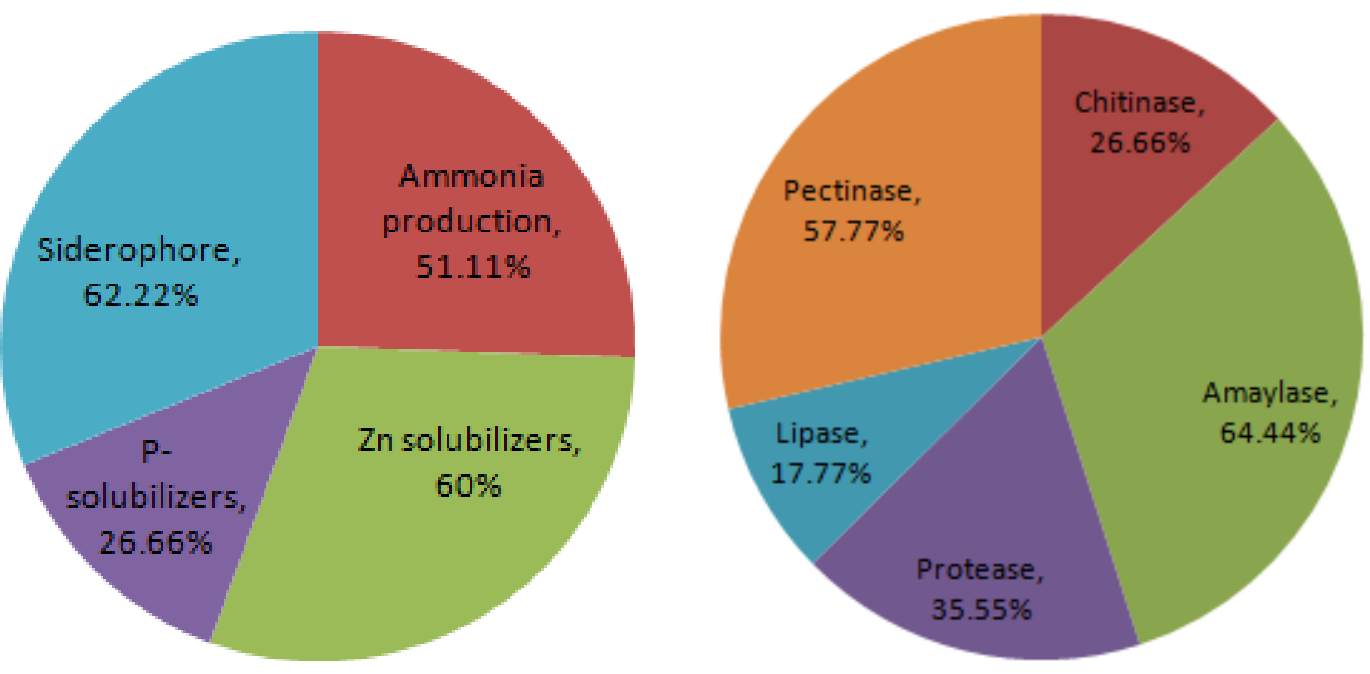

(B)

Figure 3A Production of PGP and Hydrolytic enzymes by isolates. (a-d) PGP Traits: Ammonia production, P- solubilization, Zn- solubilization and Siderophore production. (e-i) Hydrolytic enzymes: Amylase, Protease, Lipase, Pectinase and chitinase production. Figure 3B Percentage of bacterial isolates for positive reactions with (i) PGP traits, (ii) Hydrolytic enzymes.

Journal of Experimental Biology and Agricultural Sciences http://www.jebas.org 
Table 4 Assessment and ranking of rhizobacterial isolates based on in- vitro multifarious plant growth promoting, antifungal and antagonistic activities through bonitur scale

\begin{tabular}{|c|c|c|c|c|c|c|c|c|c|c|c|c|c|c|}
\hline \multirow[b]{2}{*}{ Region } & \multirow[b]{2}{*}{$\begin{array}{c}\text { Bacterial } \\
\text { isolates }\end{array}$} & \multicolumn{4}{|c|}{$\begin{array}{l}\text { Multifarious plant growth promoting } \\
\text { traits }^{\text {a }}\end{array}$} & \multirow[b]{2}{*}{ 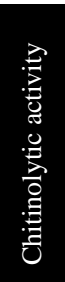 } & \multicolumn{4}{|c|}{ Hydrolytic enzymes ${ }^{a}$} & \multicolumn{2}{|c|}{$\begin{array}{l}\text { Antagonistic } \\
\text { activity }^{\mathrm{b}}\end{array}$} & \multirow[b]{2}{*}{$\begin{array}{c}\text { Total } \\
\text { assessment } \\
\text { points } \\
(\Sigma=29)\end{array}$} & \multirow[b]{2}{*}{ Rank } \\
\hline & & 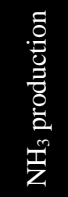 & 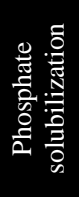 & 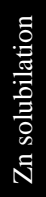 & 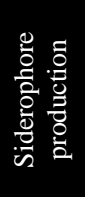 & & 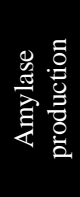 & 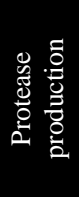 & 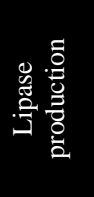 & 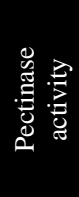 & F1 & $\mathrm{F} 2$ & & \\
\hline \multirow{9}{*}{ Almora } & A1 & 1 & 0 & 2 & 0 & 0 & 1 & 1 & 1 & 2 & 2 & 1 & 11 & 6 \\
\hline & $\mathrm{A} 2$ & 0 & 0 & 0 & 3 & 0 & 1 & 1 & 0 & 2 & 1 & 1 & 9 & 7 \\
\hline & A3 & 0 & 0 & 1 & 0 & 0 & 1 & 0 & 1 & 2 & 1 & 1 & 7 & 9 \\
\hline & A4 & 1 & 0 & 0 & 1 & 1 & 1 & 0 & 0 & 1 & 1 & 1 & 7 & 10 \\
\hline & A6 & 1 & 1 & 1 & 0 & 0 & 1 & 2 & 1 & 1 & 1 & 1 & 10 & 7 \\
\hline & A12 & 0 & 0 & & 2 & 0 & 0 & 0 & 0 & 1 & 1 & 1 & 6 & 10 \\
\hline & A15 & 1 & 3 & 0 & 0 & 0 & 0 & 0 & 1 & 1 & 1 & 1 & 8 & 8 \\
\hline & A19 & 1 & 0 & 1 & 0 & 0 & 1 & 0 & 0 & 1 & 1 & 1 & 6 & 10 \\
\hline & A21 & 0 & 0 & 1 & 0 & 1 & 1 & 0 & 0 & 1 & 1 & 1 & 6 & 10 \\
\hline \multirow{9}{*}{ Pantnagar } & $\mathrm{P} 1$ & 1 & 0 & 1 & 0 & 0 & 1 & 1 & 0 & 0 & 2 & 2 & 8 & 8 \\
\hline & $\mathrm{P} 2$ & 1 & 0 & 1 & 1 & 0 & 1 & 0 & 0 & 3 & 2 & 2 & 11 & 6 \\
\hline & P3 & 0 & 0 & 1 & 2 & 0 & 1 & 0 & 1 & 0 & 2 & 1 & 8 & 8 \\
\hline & $\mathrm{P} 4$ & 0 & 0 & 1 & 0 & 1 & 0 & 0 & 0 & 0 & 1 & 2 & 5 & 11 \\
\hline & $\mathrm{P} 5$ & 0 & 0 & 0 & 1 & 0 & 0 & 0 & 0 & 0 & 1 & 2 & 4 & 12 \\
\hline & P6 & 1 & 1 & 1 & 2 & 0 & 0 & 0 & 0 & 2 & 1 & 2 & 10 & 7 \\
\hline & $\mathrm{P} 7$ & 0 & 0 & 0 & 0 & 0 & 1 & 1 & 0 & 0 & 2 & 1 & 5 & 11 \\
\hline & P9 & 1 & 2 & 1 & 1 & 0 & 1 & 1 & 0 & 0 & 2 & 1 & 10 & 6 \\
\hline & $\mathrm{P} 10$ & 1 & 2 & 2 & 2 & 3 & 2 & 3 & 0 & 3 & 3 & 3 & 24 & 1 \\
\hline \multirow{10}{*}{$\begin{array}{l}\text { Uttar } \\
\text { Pradesh }\end{array}$} & UP1 & 1 & 0 & 1 & 0 & 0 & 2 & 2 & 0 & 1 & 1 & 1 & 9 & 8 \\
\hline & UP2 & 1 & 0 & 3 & 0 & 1 & 1 & 1 & 0 & 1 & 1 & 1 & 10 & 7 \\
\hline & UP3 & 0 & 0 & 2 & 2 & 1 & 0 & 0 & 1 & 0 & 2 & 2 & 10 & 7 \\
\hline & UP4 & 1 & 0 & 1 & 1 & 0 & 1 & 1 & 0 & 0 & 2 & 1 & 8 & 8 \\
\hline & UP5 & 0 & 0 & 1 & 1 & 0 & 0 & 0 & 0 & 0 & 2 & 2 & 6 & 10 \\
\hline & UP6 & 0 & 0 & 1 & 2 & 0 & 0 & 0 & 0 & 1 & 1 & 1 & 6 & 10 \\
\hline & UP7 & 1 & 0 & 0 & 0 & 0 & 0 & 0 & 0 & 1 & 1 & 1 & 4 & 12 \\
\hline & UP9 & 0 & 0 & 0 & 0 & 0 & 1 & 1 & 0 & 1 & 1 & 1 & 5 & 11 \\
\hline & UP10 & 0 & 2 & 2 & 1 & 0 & 1 & 1 & 0 & 0 & 1 & 2 & 10 & 7 \\
\hline & UP11 & 1 & 3 & 2 & 3 & 2 & 1 & 1 & 1 & 1 & 3 & 3 & 21 & 2 \\
\hline \multirow{8}{*}{$\begin{array}{l}\text { Madhya } \\
\text { Pradesh }\end{array}$} & MP4 & 1 & 0 & 1 & 1 & 0 & 0 & 0 & 0 & 2 & 1 & 1 & 7 & 9 \\
\hline & MP5 & 1 & 1 & 1 & 2 & 0 & 1 & 1 & 0 & 1 & 1 & 2 & 11 & 6 \\
\hline & MP12 & 0 & 1 & 0 & 0 & 0 & 1 & 1 & 0 & 1 & 1 & 1 & 6 & 10 \\
\hline & MP14 & 1 & 2 & 0 & 1 & 1 & 3 & 2 & 0 & 0 & 2 & 1 & 13 & 5 \\
\hline & MP16 & 1 & 0 & 1 & 2 & 0 & 1 & 1 & 0 & 1 & 2 & 1 & 10 & 6 \\
\hline & MP17 & 0 & 2 & 2 & 0 & 3 & 3 & 3 & 1 & 0 & 3 & 1 & 18 & 3 \\
\hline & MP20 & 0 & 0 & 1 & 0 & 0 & 1 & 1 & 0 & 1 & 2 & 1 & 7 & 9 \\
\hline & MP22 & 0 & 0 & 0 & 2 & 0 & 0 & 0 & 0 & 1 & 1 & 1 & 5 & 11 \\
\hline \multirow{9}{*}{ Maharashtra } & MH6 & 0 & 0 & 0 & 1 & 0 & 0 & 0 & 0 & 1 & 2 & 1 & 5 & 11 \\
\hline & MH10 & 1 & 0 & 0 & 0 & 0 & 1 & 1 & 0 & 0 & 1 & 1 & 5 & 11 \\
\hline & MH11 & 1 & 0 & 0 & 1 & 0 & 1 & 1 & 0 & 0 & 2 & 1 & 7 & 9 \\
\hline & MH12 & 0 & 2 & 0 & 1 & 1 & 3 & 3 & 1 & 0 & 2 & 3 & 16 & 4 \\
\hline & MH13 & 1 & 2 & 2 & 2 & 1 & 3 & 3 & 0 & 0 & 3 & 3 & 21 & 2 \\
\hline & MH14 & 0 & 1 & 1 & 0 & 0 & 1 & 1 & 0 & 0 & 2 & 1 & 7 & 9 \\
\hline & MH16 & 0 & 2 & 0 & 1 & 0 & 0 & 0 & 0 & 0 & 1 & 2 & 6 & 10 \\
\hline & MH17 & 1 & 0 & 1 & 1 & 0 & 1 & 1 & 0 & 0 & 2 & 1 & 8 & 8 \\
\hline & MH20 & 1 & 0 & 0 & 1 & 0 & 0 & 0 & 0 & 0 & 1 & 1 & 4 & 12 \\
\hline
\end{tabular}

${ }^{a}$ PGP and hydrolytic enzymes traits points specification $(+=1 ;++=2 ;+++=3)$

$\mathrm{F} 1=$ test fungus $B$. sorokiniana $; \mathrm{F} 2=$ test fungus $A$. triticina

${ }^{\mathrm{b}}$ Antagonistic activity $=(1=10-30 \% ; 2=31-50 \% ; 3=51-70 \%)$ 
scored maximum points $(\Sigma=24)$ followed by UP11 $(\Sigma=21)$, MH13 $(\Sigma=21), \operatorname{MP17}(\Sigma=18), \operatorname{MH} 12(\Sigma=16)$ and MP14 $(\Sigma$ $=13$ ). Bonitur scale has been used to select elite strains with high plant growth promotion potential and antifungal traits in vitro (El-Sayed et al., 2014; Dheeman et al., 2020). Therefore, the production of lytic enzymes and multiple PGP traits could be a prime reason for the plant growth promotion and disease suppressing ability of bacterial antagonists.

\subsection{Morphological and biochemical characterization of poten} bacterial antagonists

Morphology and in vitro biochemical characteristics are the primary step in bacterial identification and gives presumptive identification (Saqib et al., 2020). The morphological and biochemical characteristics of the six potent bacterial antagonists were determined (Table 5). The variation was observed in the color, margin, and shape of the isolates. Colonies were creamy and white; rough to smooth; with regular to irregular edges. Gram's reaction differentiates the six strains. Four isolates P10, UP11, MH13 \& MH12 were gram positive rods, isolate MP14 was gram positive cocci present in bunches and MP17 was gram positive filamentous. Based on morphological properties and gram's reaction isolates P10, UP11, MH13 \& MH12 were belonging to genera Bacillus, MP14 Staphylococcus and MP17 Streptomyces. The bacterial isolates differed in their biochemical characteristics. Four Bacillus strains were catalase and voges-proskauer positive, whereas urease and methyl red negative. The finding is supported by the results of Prajakta et al., (2019). Staphylococus strain was catalase, methyl red, and urease positive whereas voges-proskauer negative. The biochemical test for the strain of genera Staphylococus is VP negative and MR positive (Mutmainnah et al., 2020). Streptomyces strain was catalase and urease positive whereas methyl red and voges-proskauer negative. The genus, Streptomyces, can be distinguished from other bacterial groups based on their distinctive morphological, physiological, and biochemical features. Isolate VITAKN showed positive for Gram's staining test, methyl red test while, negative for mannitol test, indole, and Voges Proskauer's test (Ishaque et al., 2020).

The carbohydrate utilization profile was indicative of metabolic diversity among six potent isolates. The isolates MP17 utilized a maximum of 20 substrates, followed by P10 and UP11 (17 substrates), MH13 (16 substrates), MP14 (13 substrates), and MH12 (9 substrates) from a total of 35 substrates (Table 6). This test provides a "metabolic fingerprint" of the potent antagonist and was used to group the isolates into two distinct clusters (Figure 4). Cluster I, included two isolates P10 and MP17 placed at a distance in between of 0.49-0.64 on Jaccard's scale. Cluster II consisted of three isolates UP11, MH13, MP14. UP11 and MH13 were 100\% similar, isolate MP12 was on a separate lineage showing the least similarity to all the other isolates. The $\mathrm{C}$ substrate utilization pattern is strain specific. The strains showing similar C utilization patterns were closely placed in the cluster (Singh et al., 2019b).

\subsection{Molecular identification of potent bacterial antagonists}

The 16S rDNA sequencing is still the most reliable and frequently used technique for the identification of microorganisms (Pomastowski et al., 2019). Through 16S rDNA sequencing, six potent antagonistic isolates P10, UP11, MH13 and MH12, MP17 \& MP14 were identified as Bacillus methylotrophicus (MN099430.1), Bacillus subtilis (MN099431.1), Bacillus sp.

Table 5 Morphological and biochemical characteristics of potent bacterial antagonists

\begin{tabular}{|c|c|c|c|c|c|c|}
\hline \multirow[t]{2}{*}{ Isolates } & \multirow[t]{2}{*}{ Colony morphology } & \multirow{2}{*}{$\begin{array}{l}\text { Gram's reaction } \\
\text { observation }\end{array}$} & \multicolumn{4}{|c|}{ Biochemical activities } \\
\hline & & & Catalase & Urease & Methyl red & Voges Proskauer \\
\hline P10 & creamy with irregular edges & Gram positive, rods & + & - & - & + \\
\hline UP11 & creamy with irregular edges & Gram positive, rods & + & - & - & + \\
\hline MH13 & creamy with irregular edges & Gram positive, rods & + & - & - & + \\
\hline MP17 & $\begin{array}{l}\text { Discrete, granular, powdery white } \\
\text { colonies with regular edges }\end{array}$ & Gram positive, rods & + & + & - & - \\
\hline MP14 & $\begin{array}{l}\text { round, usually golden- } \\
\text { yellow colonies }\end{array}$ & $\begin{array}{l}\text { Gram positive, } \\
\text { coccus }\end{array}$ & + & + & + & - \\
\hline MH12 & Spherical White color colonies & $\begin{array}{l}\text { Gram positive, } \\
\text { filamentous }\end{array}$ & + & - & - & + \\
\hline
\end{tabular}

Journal of Experimental Biology and Agricultural Sciences http://www.jebas.org 


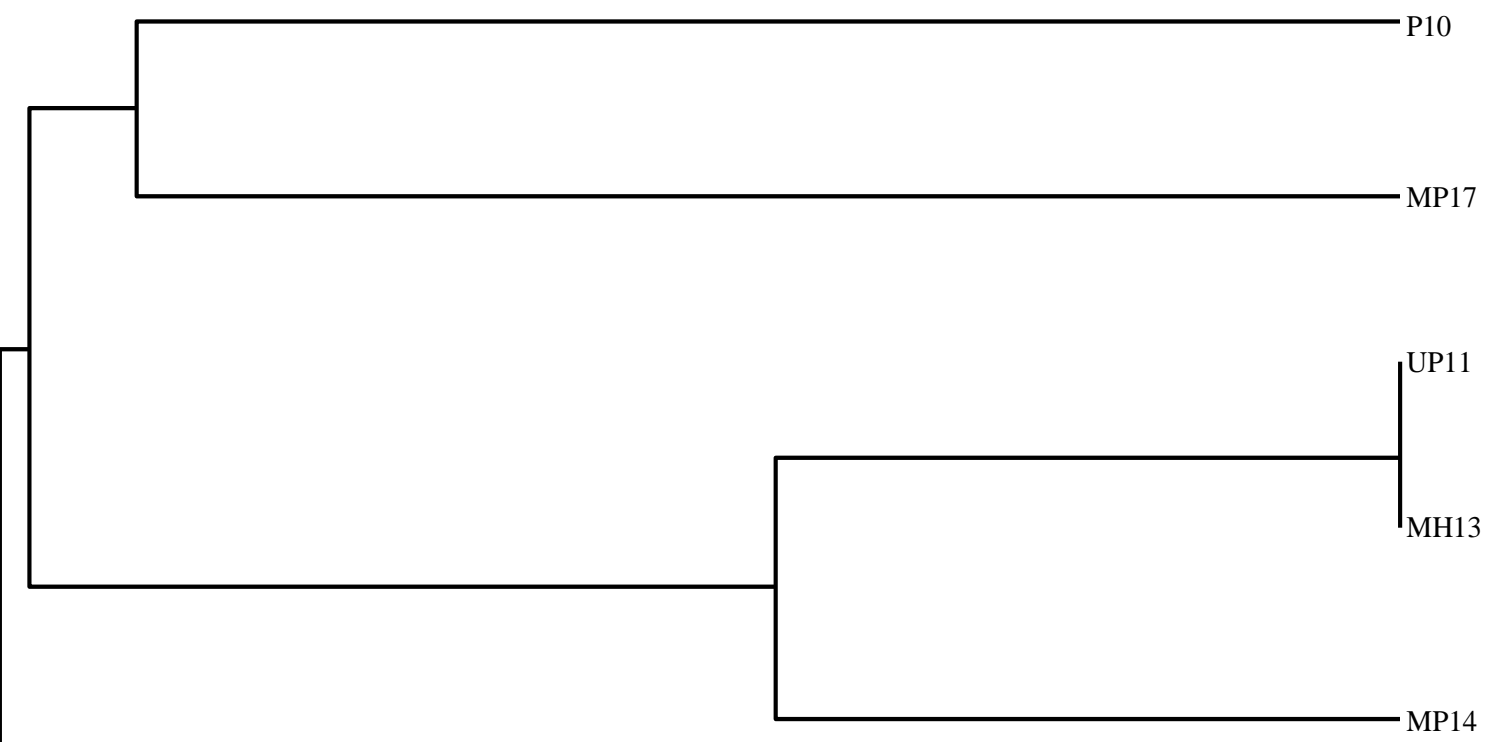

\begin{tabular}{c|c|c|c|c|c|c|c|c|c|c|c|}
\hline \\
0.28
\end{tabular}

Figure 4 UPGMA-dendrogram based on the carbohydrate utilization profile of six potential bacterial antagonists. The tree is constructed using NTSYSpc version 2.0 software by calculating jaccard coefficient.

(MN099432.1), Lysinibacillus sp. (MN099433.1), Streptomyces sp. (MN099435.1) Staphylococcus epidermidis (MN099434.1 respectively. The neighbor joining tree reflected the phylogenetic relationships within six isolates (Figure 5). Bacillus and Streptomyces have been extensively studied for its antagonistic PGPR activities (Hossain \& Rahman, 2014; Lee et al., 2017; Thennaras et al., 2019; Ali et al., 2020).

\section{Conclusion}

The present study underlines the screening of rhizobacteria for multiple PGP and biocontrol traits and molecular identification of the promising isolates. Based on in vitro dual plate assay six isolates viz., Bacillus methylotrophicus (MN099430.1), Bacillus subtilis (MN099431.1), Bacillus sp. (MN099432.1) Streptomyces sp. (MN099435.1), Lysinibacillus sp. (MN099433.1), and Staphylococcus epidermidis (MN099434.1) (out of the 45 rhizobacteria) markedly suppress the mycelia growth of tested fungus. Among them, three isolates Bacillus methylotrophicus, Bacillus subtilis, and Bacillus sp. showed invitro antagonism against both foliar blight pathogens. Therefore, this is the first report that identified the bacterial antagonists against the foliar blight complex of wheat. Findings suggested that selected isolates have the potential to be used as a biocontrol agent against the foliar blight complex. Nevertheless, to determine the disease suppression efficacy of the isolates in the natural soil environment field trial must be conducted in the future.

The submitted manuscript is original, unpublished and not under simultaneous consideration with other journals.

\section{Acknowledgment}

Authors thanks Department of Microbiology GBPUA\&T, Pantnagar Uttarakhand for providing facilities and working environment. 


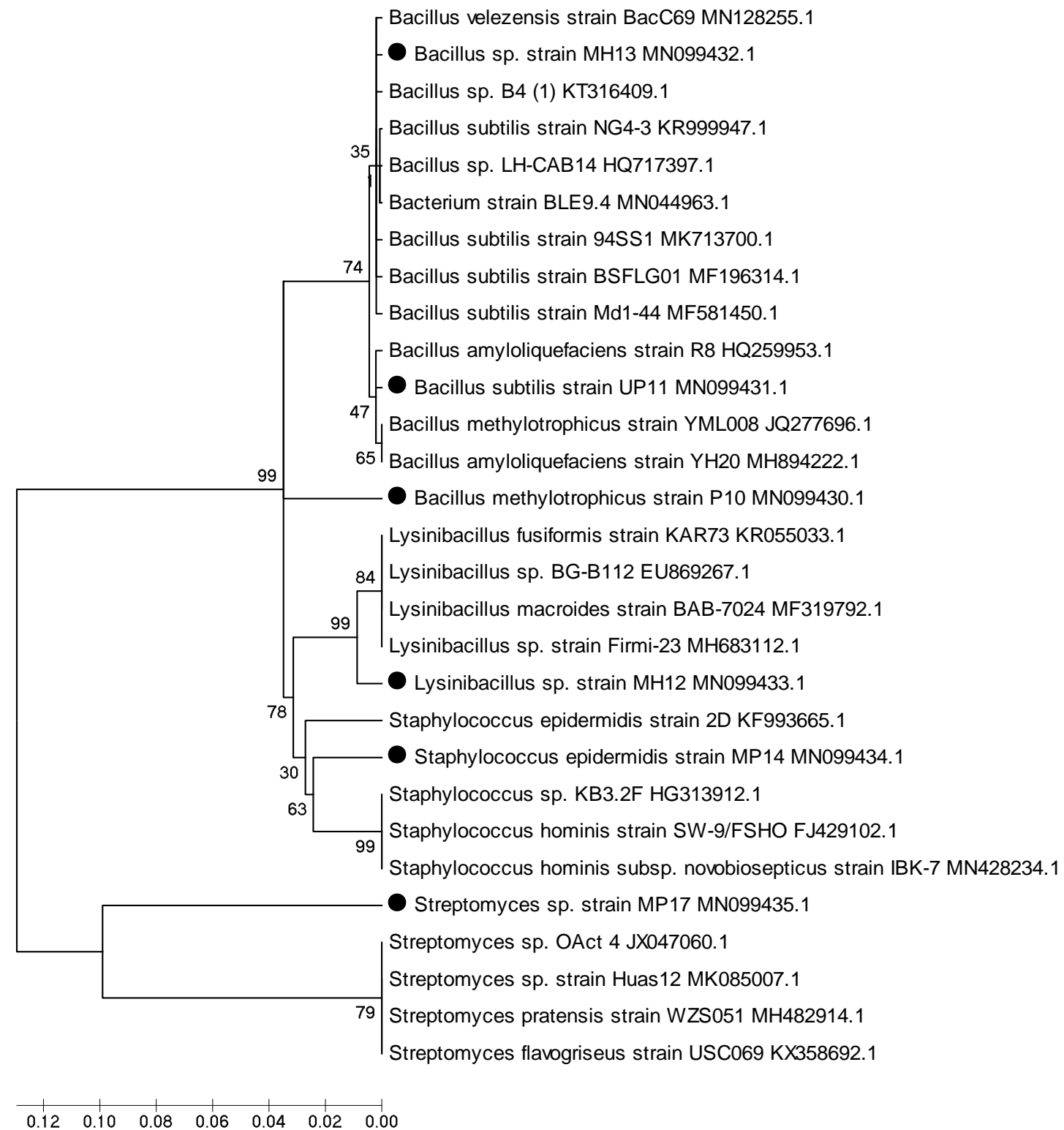

Figure 5 Phylogenetic tree of six potent bacterial antagonists (Black dot) recovered from wheat rhizosphere. Genetic relatedness between the six isolates was inferred from Neighbor-Joining tree based evolutionary analyses with a Bootstrap value of 1000. The numbers given over branches indicate bootstrap coefficient. The phylogenetic tree was constructed using MEGA 7.0 software.

\section{References}

Acharya K, Dutta AK, Pradhan P (2011) 'Bipolaris sorokiniana'(Sacc.) Shoem, the most destructive wheat fungal pathogen in the warmer areas. Australian Journal of Crop Science 5(9):1064.

Ali M, Baek KH (2020) Jasmonic acid signaling pathway in response to abiotic stresses in plants. International Journal of Molecular Sciences 21(2):621.
Ali S, Hameed S, Shahid M, Iqbal M, Lazarovits G, Imran A (2020) Functional characterization of potential PGPR exhibiting broad-spectrum antifungal activity. Microbiological Research 232: 126389.

Baqir M, Shah AB, Kothari R, Singh RP (2018) Carbon sequestration potential of plantation forestry and improvements in soil nutrient status in a subtropical area of northern India. Environmental Sustainability 1(4): 383-392.

Journal of Experimental Biology and Agricultural Sciences http://www.jebas.org 
Bueis T, Turrión MB, Bravo F, Pando V, Muscolo A (2018) Factors determining enzyme activities in soils under Pinus halepensis and Pinus sylvestris plantations in Spain: a basis for establishing sustainable forest management strategies. Annals of Forest Science 75(1):34.

Cappuccino JG, Sherman N (1996) Microbiology, A Laboratory Manual, 215-224.

Dal Bello GM, Monaco CI, Sisterna MN, Nico AI (2008) Relationship between an in vitro and greenhouse assay for biological control of Bipolaris sorokiniana-induced seedling blight of wheat. Biological Agriculture \& Horticulture 26(2):103-119.

Dheeman S, Baliyan N, Dubey RC, Maheshwari DK, Kumar S, Chen L (2020) Combined effects of rhizo-competitive rhizosphere and non-rhizosphere Bacillus in plant growth promotion and yield improvement of Eleusine coracana (Ragi). Canadian Journal of Microbiology 66(2):111-124.

Dutta J, Thakur D (2017) Evaluation of multifarious plant growth promoting traits, antagonistic potential and phylogenetic affiliation of rhizobacteria associated with commercial tea plants grown in Darjeeling, India. PloS one 12(8): e0182302.

El-Sayed WS, Akhkha A, El-Nagga M, Elbadry M (2014) In vitro antagonistic activity, plant growth promoting traits and phylogenetic affiliation of rhizobacteria associated with wild plants grown in arid soil. Frontiers in microbiology 5:651, doi: 10.3389/fmicb.2014.00651.

Gouda S, Kerry RG, Das G, Paramithiotis S, Shin HS, Patra JK (2018) Revitalization of plant growth promoting rhizobacteria for sustainable development in agriculture. Microbiological Research 206:131-140.

Gupta PK, Chand R, Vasistha NK, Pandey SP, Kumar U, Mishra VK, Joshi AK (2018) Spot blotch disease of wheat: the current status of research on genetics and breeding. Plant Pathology 67(3):508-531.

Hazarika DJ, Goswami G, Gautom T, Parveen A, Das P, Barooah M, Boro RC (2019) Lipopeptide mediated biocontrol activity of endophytic Bacillus subtilis against fungal phytopathogens. BMC Microbiology 19(1):71.

Hossain MN, Rahman MM (2014) Antagonistic activity of antibiotic producing Streptomyces sp. against fish and human pathogenic bacteria. Brazilian Archives of Biology and Technology 257(2): 233-237.

Inbar Y, Boehm MJ, Hoitink HA (1991) Hydrolysis of fluorescein diacetate in sphagnum peat container media for predicting suppressiveness to damping-off caused by Pythium ultimum. Soil Biology and Biochemistry 23(5): 479-483.

Ishaque NM, Burgsdorf I, Limlingan Malit JJ, Saha S, Teta R, Ewe D, Saurav K (2020) Isolation, Genomic and Metabolomic Characterization of Streptomyces tendae VITAKN with Quorum Sensing Inhibitory Activity from Southern India. Microorganisms 8(1):121

Jadoon S, Afzal A, Asad SA, Sultan T, Tabassam T, Umer M, Asif M (2019) Plant growth promoting traits of rhizobacteria isolated from potato (Solanum tuberosum L.) and their antifungal activity against Fusarium oxysporum. Journal of Animal and Plant Sciences 29(4):1026-1036.

Jain D, Sanadhya S, Saheewala H, Maheshwari D, Shukwal A, Singh PB, Singh A (2020) Molecular Diversity Analysis of Plant Growth Promoting Rhizobium Isolated from Groundnut and Evaluation of Their Field Efficacy. Current Microbiology $77: 1550-1557$.

Jian S, Li J, Chen J, Wang G, Mayes MA, Dzantor K ELuo Y (2016). Soil extracellular enzyme activities, soil carbon and nitrogen storage under nitrogen fertilization: A meta-analysis. Soil Biology and Biochemistry 101:32-43.

Joshi AK, Chand R (2002) Variation and inheritance of leaf angle, and its association with spot blotch (Bipolaris sorokiniana) severity in wheat (Triticum aestivum). Euphytica 124(3):283-291

Joshi BH, Dhingani RM (2020) Assessment and selection of multi-trait plant growth promoting bacteria associated with rice rhizosphere. Journal of Pharmacognosy and Phytochemistry 9(2):942-948.

Joshi S, Jaggi V, Tiwari S, Sah VK, Sahgal M (2019) Multitrate phosphate solubilizing bacteria from Dalbergia sissoo Roxb. Rhizosphere in natural forests of Indian Central Himalayas. Environment and Ecology 37 (3A):894-908.

Kalam S, Basu A, Podile AR (2020) Functional and molecular characterization of plant growth promoting Bacillus isolates from tomato rhizosphere. Heliyon 6(8):e04734.

Kandeler E, Gerber H (1988) Short-term assay of soil urease activity using colorimetric determination of ammonium. Biology and Fertility of Soils 6(1): 68-72.

Kasana RC, Salwan R, Dhar H, Dutt S, Gulati A (2008) A rapid and easy method for the detection of microbial cellulases on agar plates using Gram's iodine. Current Microbiology 57(5): 503-507.

Kaur T, Rani R, Manhas RK (2019) Biocontrol and plant growth promoting potential of phylogenetically new Streptomyces $s p$. MR14 of rhizospheric origin. AMB Express 9(1): 125. 
Krechel A, Faupel A, Hallmann J, Ulrich A, Berg G (2002) Potatoassociated bacteria and their antagonistic potential towards plantpathogenic fungi and the plant-parasitic nematode Meloidogyne incognita (Kofoid and White) Chitwood. Canadian Journal of microbiology 48:772-786.

Lee T, Park D, Kim K, Lim SM, Yu NH, Kim S (2017) Characterization of Bacillus amyloliquefaciens DA12 showing potent antifungal activity against mycotoxigenic Fusarium species. Plant Pathology Journal 33(5): 499-507.

Li J, Cooper JM, Li Y, Yang X, Zhao B (2015) Soil microbial community structure and function are significantly affected by long-term organic and mineral fertilization regimes in the North China Plain. Applied Soil Ecology 96:75-87.

Liu J, Chen J, Chen G, Guo J, Li Y (2020) Enzyme stoichiometry indicates the variation of microbial nutrient requirements at different soil depths in subtropical forests. PloS one 15(2): e0220599.

Mahajan G, Kumar V, Chauhan BS (2017) Rice production in India. In Rice production worldwide Springer, Cham: 53-91.

Majeed MK, Abbasi S, Hameed A, Rahim NI (2015) Isolation and characterization of plant growth-promoting rhizobacteria from wheat rhizosphere and their effect on plant growth promotion. Frontiers in Microbiology 6: 198.

Maurya BR, Singh V, Dhyani PP (2011) Enzymatic activities and microbial population in agric-soils of almora district of Central Himalaya as influenced by altitudes. International Journal of Soil Science 6(4):238.

Miller RW, Donochue RL (1990) Soils: An introduction to soils and plant growth. 6th edn. Prentice-Hall International Inc.

Monteiro P, Borba MP, Van Der Sand ST (2017) Evaluation of the antifungal activity of Streptomyces sp. on Bipolaris sorokiniana and the growth promotion of wheat plants. Journal of Agricultural Science 9(12): 229

Mutmainnah B, Baktir A, Ni'matuzahroh NM (2020) Characteristics of Methicillin-Resistant Staphylococcus aureus (MRSA) and Methicillin Sensitive Staphylococcus aureus (MSSA) and their inhibitory response by ethanol extract of Abrus precatorius. Biodiversitas Journal of Biological Diversity 21(9): 4076-4085.

Nafiu BS, Dong H, Cong B (2016) Principles of biological control in integrated pest management. International Journal of Applied Research and Technology 3(11):104-116.

Nannipieri P, Ascher J, Ceccherini MT, Landi L, Pietramellara G, Renella G (2017) Microbial diversity and soil functions. European journal of soil science 68(1):12-26.
Olsen SR, Cole CV, Watanabe FS, Dean CA (1954) Estimation of available $\mathrm{P}$ in soils by extraction with sodium bicarbonate. United States Department of Agriculture Circular 939.

Pomastowski P, Złoch M, Rodzik A, Ligor M, Kostrzewa M, Buszewski B (2019) Analysis of bacteria associated with honeys of different geographical and botanical origin using two different identification approaches: MALDI-TOF MS and 16S rDNA PCR technique. PloS one 14(5):e0217078.

Prajakta B M, Suvarna PP, Raghvendra SP, Alok RR (2019) Potential biocontrol and superlative plant growth promoting activity of indigenous Bacillus mojavensis PB-35 (R11) of soybean (Glycine max) rhizosphere. SN Applied Sciences 1(10):1143.

Rai M, Kon K, Ingle A, Duran N, Galdiero S, Galdiero M (2014) Broad-spectrum bioactivities of silver nanoparticles: the emerging trends and future prospects. Applied Microbiology and Biotechnology 98(5):1951-1961.

Rajwar A, Sahgal M (2016) Phylogenetic relationships of fluorescent pseudomonads deduced from the sequence analysis of 16S rRNA, Pseudomonas-specific and rpoD genes. 3 Biotech 6(1):80.

Ramadas S, Kumar T K, Singh G P (2019) Wheat Production in India: Trends and Prospects. In Global Wheat Production, IntechOpen

Rana A, Saharan B, Joshi M, Prasanna R, Kumar K, Nain L (2011) Identification of multi-trait PGPR isolates and evaluating their potential as inoculants for wheat. Annals of Microbiology 61(4):893-900.

Sadfi N, Cherif M, Fliss I, Boudabbous A, Antoun H (2001) Evaluation of bacterial isolates from salty soils and Bacillus thuringiensis strains for the biocontrol of Fusarium dry rot of potato tubers. Journal of Plant Pathology 101-117.

Saqib S, Uddin S, Zaman W, Ullah F, Ayaz A, Asghar M, Chaudhary HJ (2020) Characterization and phytostimulatory activity of bacteria isolated from tomato (Lycopersicon esculentum Mill.) rhizosphere. Microbial Pathogenesis 140:103966.

Saravanan VS, Subramoniam SR, Raj SA (2004) Assessing in vitro solubilization potential of different zinc solubilizing bacterial (ZSB) isolates. Brazilian Journal of Microbiology 35(1-2):121-125.

Schwyn B, Neiland JB (1987) Universal chemical assay for the detection and determination of siderophores. Analytical Biochemistry 160: $47-56$.

Shaheen M, Shah AA, Hameed A, Hasan F (2008) Influence of culture conditions on production and activity of protease from Bacillus subtilis BS1. Pakistan Journal of Botany 40(5): 2161-2169. 
Sharma I, Tyagi BS, Singh G, Venkatesh K, Gupta OP (2015) Enhancing wheat production-A global perspective. Indian Journal of Agricultural Sciences 85(1):3-13.

Shrestha BK, Karki HS, Groth DE, Jungkhun N, Ham JH (2016) Biological control activities of rice-associated Bacillus sp. strains against sheath blight and bacterial panicle blight of rice. PloS one 11(1).

Siddiqui ZA (2007) Biocontrol of Alternaria triticina by plant growth promoting rhizobacteria on wheat. Archives of Phytopathology and Plant Protection 40(4):301-308.

Singh R, Kumar A, Singh M, Pandey KD (2019a) Isolation and Characterization of Plant Growth Promoting Rhizobacteria from Momordica Charantia L. In PGPR amelioration in sustainable agriculture. Woodhead Publishing.

Singh UB, Singh S, Malviya D, Karthikeyan N, Imran M, Chaurasia R, Damodaran T (2019b) Integration of anti-penetrant tricyclazole, signaling molecule salicylic acid and root associated Pseudomonas fluorescens enhances suppression of Bipolaris sorokiniana in bread wheat (Triticum aestivum L.). Journal of Plant Pathology 101(4):943-954.

Sood G, Kaushal R, Panwar G, Dhiman M (2019) Effect of indigenous plant growth-promoting rhizobacteria on wheat (Triticum aestivum L.) productivity and soil nutrients. Communications in soil science and plant analysis 50(2):141-152.

Sood G, Kaushal R, Sharma M (2020) Significance of inoculation with Bacillus subtilis to alleviate drought stress in wheat (Triticum aestivum L.) Vegetos 1-11.

Tabatabai MA, Bremner JM (1969) Use of p-nitrophenyl phosphate for assay of soil phosphatase activity. Soil Biology and Biochemistry 1(4): 301-307.

Tamura K, Stecher G, Peterson D, Filipski A, Kumar S (2013) MEGA6: molecular evolutionary genetics analysis version 6.0. Molecular Biology and Evolution 30(12): 2725-2729.

Tan X, Xie B, Wang J, He W, Wang X, Wei G (2014) Countyscale spatial distribution of soil enzyme activities and enzyme activity indices in agricultural land: implications for soil quality assessment. The Scientific World Journal. Article ID 535768 https://doi.org/10.1155/2014/535768.

Thalmann A (1968) Zur Methodik der Bestimmung der Dehydrogenase aktivität im Boden mittels Triphenyltetrazolium chlorid (TTC). Landwirtsch Forsch 21: 249-258.
Thennaras S, Natarajan E, Muthukumar B (2019) Novel Plant Growth Promoting Rhizobacteria from Rhizospheres of Date Palm (Phoenix dactylifera): 16S rRNA Typing and Phylogenetic Analyses Reveal their Distinct Identity. Research \& Reviews: A Journal of Microbiology and Virology 9(1):11-25.

Tsegaye Z, Gizaw B, Tefera G, Feleke A, Chaniyalew S, Alemu T, Assefa F (2019) isolation and biochemical characterization of plant growth promoting (pgp) bacteria colonizing the rhizosphere of Tef crop during the seedling stage. Biomedical Journal of Scientific \& Technical Research 14:013-027.

Ullah S, Ai C, Huang S, Zhang, J, Jia L, Ma J, He P (2019) The responses of extracellular enzyme activities and microbial community composition under nitrogen addition in an upland soil. PloS one 14(9): e0223026.

Veeraragavan S, Duraisamy R, Mani S (2018) Seasonal variation of soil enzyme activities in relation to nutrient and carbon cycling in Senna alata (L.) Roxb invaded sites of Puducherry region, India. Geology, Ecology, and Landscapes 2(3):155-168.

Verma JP, Jaiswal DK, Maurya PK (2016) Screening of bacterial strains for developing effective pesticide-tolerant plant growthpromoting microbial consortia from rhizosphere soils of vegetable fields of eastern Uttar Pradesh, India. Energy, Ecology and Environment 1(6):408-418

Verma S, Chug A, Singh AP (2020) Recent advancements in image-based prediction models for diagnosis of plant diseases. In Proceedings of 3rd International Conference on Computer Vision and Image Processing Springer, Singapore: 365-377.

Villa-Rodriguez E, Parra-Cota F, Castro-Longoria E, LópezCervantes J, de los Santos-Villalobos S (2019) Bacillus subtilis TE3: a promising biological control agent against Bipolaris sorokiniana, the causal agent of spot blotch in wheat (Triticum turgidum L. subsp. durum). Biological Control 132:135-143.

Villarreal-Delgado MF, Villa-Rodríguez ED, Cira-Chávez LA, Estrada-Alvarado MI, Parra-Cota FI, de los Santos-Villalobos S (2018) The genus Bacillus as a biological control agent and its implications in the agricultural biosecurity. Revista Mexicana de Fitopatología 36:95-130.

Walkley A, Black La (1934) An examination of the Degtjareff method for determining soil organic matter, and a proposed modification of the chromic acid titration method. Soil Science 34:29-38.

Wang C, Lu X, Mori T, Mao Q, Zhou K, Zhou G, Mo J (2018) Responses of soil microbial community to continuous 
experimental nitrogen additions for 13 years in a nitrogen-rich tropical forest. Soil Biology and Biochemistry 121: 103-112.

Wang X, Dong S, Gao Q, Zhou H, Liu S, Su X, Li Y (2014) Effects of short-term and long-term warming on soil nutrients, microbial biomass and enzyme activities in an alpine meadow on the Qinghai-Tibet Plateau of China. Soil Biology and Biochemistry 76:140-142.

Xu WH, Wang Z, Wu F (2015) The effect of D123 wheat as a companion crop on soil enzyme activities, microbial biomass and microbial communities in the rhizosphere of watermelon. Frontiers in Microbiology 6:899.

Yao H, Xu J, Huang C (2003) Substrate utilization pattern, biomass and activity of microbial communities in a sequence of heavy metal-polluted paddy soils. Geoderma 115(1-2):139-148.
Yuan KN (1983) Soil Chemistry of Plant Nutrients. Science Press, Beijing.

Yue HM, Wang M, Gong WF, Zhang LQ (2018) The screening and identification of the biological control fungi Chaetomium spp. against wheat common root rot. FEMS microbiology letters 365(22): fny242.

Zhang J, Liu J, Meng L, Ma Z, Tang X, Cao Y, Sun L (2012) Isolation and characterization of plant growth-promoting rhizobacteria from wheat roots by wheat germ agglutinin labeled with fluorescein isothiocyanate. The Journal of Microbiology 50(2):191-198.

Zhou J, Deng Y, Shen L, Wen C, Yan Q, Ning D, Voordeckers JW (2016) Temperature mediates continental-scale diversity of microbes in forest soils. Nature Communications 7(1):1-10. 